\title{
Plants as an Alternate System for the Large Scale Production of Recombinant Therapeutic Proteins
}

\section{Bala Murugan Shanmugaraj ${ }^{2}$ and Sathishkumar Ramalingam ${ }^{1,2^{*}}$}

${ }^{1}$ Plant Genetic Engineering Laboratory, Department of Biotechnology, Bharathiar University, Coimbatore, India

${ }^{2} B U-D R D O$ Centre for Life Sciences, Bharathiar University, Coimbatore, India

"Corresponding author: Ramalingam S K, Plant Genetic Engineering Laboratory, Department of Biotechnology, Bharathiar University, Coimbatore, India, Tel: +91-9360151669; Fax: +91-422-2422387; E-mail: rsathish@buc.edu.in

Rec date: October 31, 2014, Acc date: November 03, 2014, Pub date: November 10, 2014

Copyright: (c) 2014 Ramalingam S K, et al. This is an open-access article distributed under the terms of the Creative Commons Attribution License, which permits unrestricted use, distribution, and reproduction in any medium, provided the original author and source are credited.

\section{Description}

Due to the recent advancement in transient gene expression technologies in plants, a novel area called Plant Molecular Pharming has emerged. The major advantages includes cheaper, rapid, scalable and safer therapeutics are the reality, as there won't be any natural human pathogen contamination in plant produced recombinant proteins. Researchers have expressed successfully even complex proteins e.g. fully assembled immunoglobulin in plants, which have been proved to be functionally active.

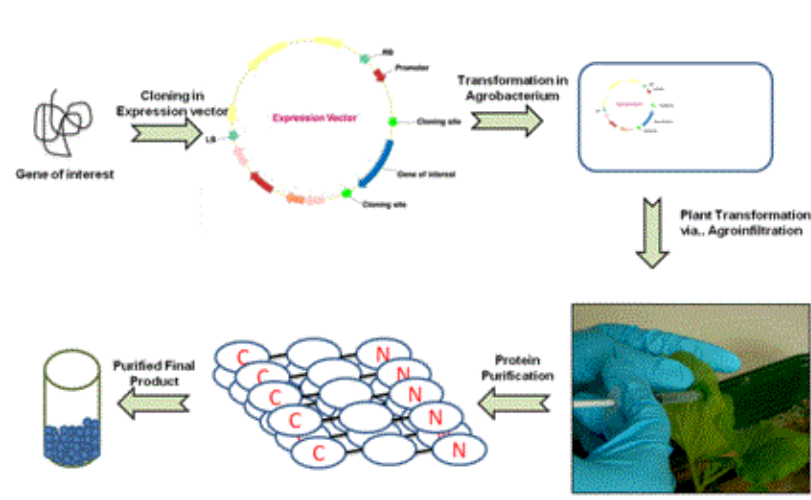

Figure 1: Overview of Transient Gene Expression in Plants for the Production of Therapeutic Proteins
However, there are still challenges to overcome that includes, difference in post translational modification and difficulties in downstream processing as plants contain millions of metabolites. Once these issues are solved, plant molecular pharming industry will become a reality and will be a big boon for the developing countries in order to produce cheaper vaccine. 